\title{
The State-Supported University Libraries of Alabama: Serving the Needs of Patrons with Disabilities
}

\section{Barbara A. Bishop}

\begin{abstract}
The Americans with Disabilities Act is a highly enforceable piece of national legislation that greatly affects public institutions of higher learning. Information gathered in a fall 1993 survey of the libraries at Alabama public universities acknowledged that while disabled populations on campuses needed to be served, they were not being served. Among the reasons given were lack of preparation on the library's part, lack of knowledge of the potentially disabled student populations on campuses, and lack of funding for needed accommodations.
\end{abstract}

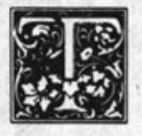

he Americans with Disabilities Act (ADA) was signed by former President George Bush in 1990. Some sections had implementation dates beginning in 1992. Title II of the ADA, which affects four-year state institutions, became effective on January 26, 1992. By this date Title II entities should have been aware of their responsibilities regarding accessibility. Self-evaluations and transition plans were to be undertaken and completed by January 1, 1993. These evaluations and transition plans, even if done by the college or university administration, were to have helped focus attention on library services to patrons with disabilities. These deadlines raise a major question: Are Alabama's public university libraries responsive to this national legislation, or do they lag behind?

Little has been written on the extent to which academic libraries have accommodated the needs of persons with disabilities. A search of the datafile Library Literature found eight articles published after 1984 that have the keywords college, survey(s), and handicapped in them. Of these eight, two were published in journals outside the United States and another article discussed the attitudes of academic librarians toward persons with disabilities. The remaining five articles surveyed patrons with disabilities and gathered information about their perceptions of library use.

While preparing the 1981 Oryx Press directory, Academic Library Facilities and Services for the Handicapped, James L. and $\mathrm{Carol} \mathrm{H}$. Thomas surveyed academic institutions in order to list "accessibility, equipment, and services of academic libraries throughout the United States and the outlying areas. ${ }^{11}$ However, this directory has never been revised and the survey was geared rather toward discovering physical access-accessible routes from parking lot to library, level thresholds, height of tables, and width of aisles-than toward overall service. There were questions regarding special equipment and services, but for the most part the questions had an architectural focus.

Barbara A. Bishop is Humanities Reference Librarian at the Ralph Brown Draughon Library, Auburn University, Auburn, Alabama. The author expresses special thanks to T. Harmon Straiton and Linda Thornton of Auburn University for their support throughout the entire project. 
The first Association of Research Libraries (ARL) Spec Kit 81 discussing disabilities needs was published in February 1982 . Although the kit did not contain a copy of the survey, the responses indicate that the survey must have gathered information about both services and facilities. The documents included were divided into the following categories: policy and procedure statements, personnel and staffing, facilities and services planning, building access, descriptions of services, and publicity or user guides. ${ }^{2}$

In 1991 Kate Ragsdale of the University of Alabama undertook a survey of ARL libraries regarding their services to patrons with disabilities. The survey was completed before the Title II 1992 implementation date; however, it generated much information that revealed the level of library awareness regarding responsibilities in terms of the ADA. This survey asked questions concerning a library's responsibility to patrons with disabilities and the need for some type of self-study. The survey instrument was published along with the survey results; again documents were included that covered everything from policies and procedures to equipment provided. Unfortunately, any conclusions drawn from the results of this survey become problematic because the sampling error is much greater than 5 percent $\left(x^{2}=17\right)$.

There has been little coordination between libraries within the state of Alabama regarding ADA compliance. Only one workshop, cosponsored by the Public Library Division and the Services to the Handicapped Round Table of the Alabama Library Association (AlaLA) in November 1991, and one session at the 1992 and 1993 AlaLA annual conventions have been conducted. The Network of Alabama Academic Libraries is cosponsoring a workshop with the Auburn University Libraries; however, this is still in the initial planning stages. ${ }^{3}$

\section{METHODOLOGY}

I became curious about what Alabama's public university libraries were doing in order to meet the needs of their patrons with disabilities and decided that a survey might provide some information. The most recent ARL Spec Kit 176 on disabilities covers a library's accessibility in terms of programs, equipment, and facilities. The survey form and results were included in the kit. However, only generalizations can be made because of the sampling error in this survey. No valid comparisons may be drawn between these data and the data generated by the survey of Alabama's university libraries.

The Association of Research Libraries Office of Management Services in Washington, D.C., was contacted for permission to use the 1992 survey in order to study public academic institutions in Alabama. After permission was received, the Alabama section of the 1993 College Blue Book was used to identify participants. The author chose any publicly funded institution offering a fouryear program of study culminating in at least a bachelor's degree. This resulted in a pool of fifteen libraries. ${ }^{4}$ In September 1993 the survey was mailed to the library directors at the fifteen institutions. By the deadline, November 1, 1993 , only eight of the fifteen surveys had been returned. Because of the small size of the survey pool, this response rate was deemed unacceptable. After a round of telephone calls and telefacsimile correspondence, fourteen of the fifteen surveys were returned. However, using the chi-square test of sampling validity, this response rate was still unacceptable as $x^{2}$ $=.067$. After one more round of telephone calls, the final survey was received which made for a highly satisfactory 100 percent return.

\section{SURVEY INSTRUMENT}

The ARL survey used for this project consisted of twenty-seven questions divided into four major categories. These sections dealt with general information, management and training, space for specialized library services, and general services. A final section allowed for general comments. The questions were primarily yes/no questions with explanations requested. Several times docu- 
mentation was requested for particular questions (see appendix A).

\section{General Information}

Questions 1 and 2 of the general information section asked whether the library provided services to its disabled student population, and whether there was an increased use of the library by students with disabilities within the past five years. Questions 3 and 4 specifically asked about building accessibility checklists and improvement in accessibility during the past five years. Question 5 asked which disabilities were addressed through library services.

Although the survey population was not large, certain trends became evident. With the exception of one library, all provide services and/or equipment designed for persons with disabilities. Approximately one-third of the respondents thought that people with disabilities had not increased their library use in the past five years. Of the two-thirds that believed usage had increased, the major reasons given were increased enrollment of disabled students followed by universitywide promotion and awareness of services. Other reasons for the greater use of libraries included the provision or promotion of better services, the improvement of services campuswide, and increased awareness of disability rights.

The literature supports the choice of increased enrollment of students with disabilities as the number one answer given for greater library use. In his book No Pity, Joseph Shapiro says, "a 1991 report by the Department of Education notes that the number of students identified with disabilities has increased every year since 1976 and is expected to continue that trend through at least the end of the century." 5 Shapiro comments that those students at present graduating from college started kindergarten or first grade protected by the Education for All Handicapped Children Act. These students have never known a time when they did not have a legal right to quality public education.

In the Profile of Handicapped Students in Postsecondary Education, published by the National Center for Education Statistics, students reporting at least one disability comprised approximately 10.5 percent of all college students. ${ }^{6}$ In the fall of 1986 the number of undergraduate students enrolled in four-year public institutions of higher learning numbered $4,296,159$. Of these four million plus students, 86,161 attended school in Alabama. ${ }^{7}$ Using the percentage of students reporting at least one disability in 1986, the potential number of disabled students in Alabama was just over nine thousand. In 1990, the number of students grew to $4,677,769$ nationwide and to 102,301 statewide. This was a growth rate of almost 7.5 percent nationally and approximately 16 percent in Alabama. ${ }^{8}$ If the percentages continued at this rate, the Alabama enrollment could have reached 118,669 undergraduates in the fall of 1994 (projected figures at the time of this study). If the 10.5 percent of students with disabilities also holds steady, then there is the potential that Alabama's public academic libraries are serving almost 12,500 students this year. Using the undergraduate enrollment figures from the 1993 College Blue Book, the fifteen Alabama institutions' total enrollment comes to 102,764 , which would equate to approximately 10,790 potential students with disabilities (see table 1).

In a 1991 article for the Chronicle of Higher Education, Laura Rothstein, a professor of law at the University of Houston Law Center, states that in the last ten years the number of persons with disabilities attending college has tripled. Rothstein writes about the responsibilities of university administrators regarding accessibility and accommodation resulting from recent court cases concerning Section 504 and the ADA. " Failure to make mandated changes could result in significant financial liability, costly litigation and loss of public image, and most important, loss of the valuable contributions that disabled individuals can make to any academic community. ${ }^{10}$ Survey respondents reported an increase in universitywide promotion and awareness of services; in part this action may be a response to the potential 
TABLE 1

POTENTIAL NUMBER OF STUDENTS WITH DISABILITIES

IN ALABAMA PUBLIC FOUR-YEAR POSTSECONDARY INSTITUTIONS

\begin{tabular}{lcr}
\hline Institution & $\begin{array}{c}\text { Undergraduate } \\
\text { Enrollment* }\end{array}$ & $\begin{array}{c}\text { Students with } \\
\text { Disabilities } \\
(10.5 \text { percent) }\end{array}$ \\
\hline Alabama A\&M & 3,533 & 370.97 \\
Alabama State & 4,697 & 493.19 \\
Auburn & 21,551 & $2,262.86$ \\
Auburn Montgomery & 6,500 & 682.50 \\
Jacksonville State & 5,797 & 608.69 \\
Livingston & 1,646 & 172.83 \\
Troy State & 4,007 & 420.74 \\
Troy State Dothan & 2,139 & 224.60 \\
Troy State Montgomery & 2,736 & 287.28 \\
University of Alabama & 16,782 & $1,762.11$ \\
University of Alabama Birmingham & 9,509 & 998.45 \\
University of Alabama Huntsville & 8,156 & 856.38 \\
Montevallo & 3,250 & 341.25 \\
North Alabama & 3,904 & 409.92 \\
South Alabama & 8,557 & 898.49 \\
Total & 102,764 & $10,790.26$ \\
\hline
\end{tabular}

* Enrollment statistics are taken from the 1993 College Blue Book.

+ This percentage is from the 1987 National Postsecondary Student Aid Study.

for litigation by an ever-growing and better informed disabled population attending colleges and universities.

Although Alabama libraries, for the most part, do not have a checklist for building accessibility, several of the directors noted that their library is either being surveyed as part of a campuswide study or the checklist is in process. Almost all acknowledge improvements in the elimination of barriers and the addition of specialized equipment in order to meet the needs of their disabled populations. During the past five years, libraries have focused on the elimination of physical barriers and the addition of specialized equipment or adaptive technologies for the disabled. Only one-third of the respondents have added specialized library services.

To the question "Which disabilities are specifically addressed through specialized library services?" only about 27 percent responded that programs were in place to meet the needs of students with learning disabilities. However, accord- ing to national studies done on enrolling freshmen, this is the fastest growing disabled population of students on college campuses. From 1983 to 1990 the total number of students reporting a learning disability has risen from .7 percent to 1.2 percent. ${ }^{11}$ Public university students reporting learning disabilities rose from .9 percent in the fall of 1991 to 1.3 percent in the fall of 1992. ${ }^{12,13}$

With the exception of one library, all provide services and/or equipment designed for persons with disabilities.

This inattention to serving persons with learning disabilities is not surprising. In a nationwide survey of academic library services provided for learningdisabled patrons, only 22 percent of the respondents knew the size of their learning-disabled student population, and over 90 percent indicated they had only minimal to moderate knowledge of 
TABLE 2

ALABAMA STUDENTS WITH LEARNING DISABILITIES*

\begin{tabular}{lccc}
\hline Institution & $\begin{array}{c}\text { All Students } \\
\text { with Disabilities }^{\dagger}\end{array}$ & $\begin{array}{c}\text { Specific Learning } \\
\text { Disability }^{-}\end{array}$ & $\%_{\text {of } \text { Total }^{\ddagger}}$ \\
\hline Auburn & 325 & 163 & 50 \\
Auburn Montgomery & 275 & 68 & 25 \\
Jacksonville State & 135 & 61 & 45 \\
Troy State Dothan & 26 & 2 & 7 \\
University of Alabama & 318 & 138 & 43 \\
University of Alabama & & & 26 \\
Birmingham & 346 & 90 & 27 \\
South Alabama & 234 & 60 & \\
\hline
\end{tabular}

* Figures are provided by campus offices serving students with disabilities and are valid for Fall Quarter 1994.

† These are actual figures, potential could be greater according to national percentages.

$\ddagger$ National figure is 12.2 percent based on the 1987 National Postsecondary Student Aid Study.

learning disabilities. ${ }^{14}$ Telephone calls to several Alabama campus offices serving students with disabilities show that many of the students registered with these offices have a specific learning disability (see table 2).

A person with a disability is not required to take advantage of a service offered or even disclose the disability. Individuals may not know that they have disabilities, or that they have legal rights because of a disability. As a result, many of the offices that provide services to these students may be working with only a fraction of the disabled populations on their campuses. Alabama librarians need to begin identifying the disabled student populations and then to consider how existing services best can be utilized in serving them.

\section{Management and Training}

The management and training section contained questions 6 through 15 . These questions examined the units on campus with which the library cooperates (question 6); as well as funding, cost analyses, planning, and awareness (questions 7 to 11). Questions 12 through 16 concern staffing and training issues.

In terms of management and training all the respondents indicated that they cooperate with a variety of other campus entities ranging from the student government (low response) to student services (high response). Eighty percent provide funding for special library services out of their library budget, yet none have completed cost analyses for providing these services, and only 20 percent have prepared planning documents or recommendations regarding these services. This appears to validate the ARL study in which 75 percent of the respondents indicated funding came from the library budget, about 95 percent had not done a cost analysis, and only about 27 percent had prepared planning documents. ${ }^{15}$

Training within Alabama's libraries does happen. Many of the libraries provide some type of training in disability sensitivity for most of the staff who work with the public, including circulation, all public service areas, and library administration. However, only six libraries have assigned a staff member to coordinate library services; this person usually spends less than half time on this responsibility.

Alabama's university libraries need to do a better job in preparing to serve their disabled student populations. First, they should identify the campus officer most responsible for advocating the rights of students with disabilities. All fifteen public universities within Alabama have either a specific office or officer who does this, yet only six of the respondents indicated they utilized this person.

Second, the librarians need to do evaluations on existing services and cost 
analyses for potential services. Then they must identify alternate sources of additional funding beyond their own budget. In some cases, cost sharing across offices and departments can work. Sometimes service organizations are looking for ways to invest in their communities by donating funds for specific projects.

Finally, the libraries need to create a job description that includes the responsibility for library service for persons with disabilities. This staff member would communicate with the various campus departments and make recommendations to the library administration for planning and training.

\section{Space for Specialized Library Services}

Questions 16 through 19 examine the physical space provided for patrons with disabilities, its location and hours it is available, and the assistance provided within it. Alabama academic libraries are in the process of providing special space for their students with disabilities. Several libraries are under construction or renovation, and their plans include dedicated space for handicapped use. Many have scattered workstations, and one library explicitly stated that integration is its goal. The spaces are available whenever the libraries are open, and assistance usually is provided by the reference staff.

\section{Services}

The final section of questions concerned services. Policies and procedures were addressed by questions 20 through 23. Adaptive equipment needs were addressed by questions 24 through 27.

Written policies for providing library services for the disabled seldom exist. Two institutions have written policies; two others have policies in development. Auburn University has two separate statements in its Guide to the Auburn University Libraries and in A Guide to the Ralph Brown Draughon Library. These statements say that "services for users with disabilities are available on an asneeded basis" followed by a contact number. ${ }^{16}$ Troy State University's un- published policy statement "Personal Help for Disabled Patrons" touches briefly on the library staff's responsibilities in regards to their students with disabilities.

\section{Alabama's university libraries need to do a better job in preparing to serve their disabled student populations.}

Services provided for Alabama students with disabilities range from the paging of materials from the stacks (about 93 percent) to the recording of textbooks or other reading materials (about 7 percent). Only three libraries give extended loan periods and four give specialized bibliographic instruction. One library responded that it gives spousal checkout privileges, and Alabama A \& M provides limited signing for the deaf. The University of Alabama has speech-synthesis capabilities available on their OPAC, and Auburn University plans to have this capability available soon.

There are a variety of ways in which the libraries communicate with their students. Almost half (seven) have a suggestion box, and only six consult directly with individuals with disabilities. A couple of libraries surveyed their students; many others consulted with other campus offices or professional consultants.

The question "Do the blind library patrons at your institution use Braille?" elicited some interesting answers. Of the ten written responses, seven either did not know or answered no to the question. One director replied that "we have had no calls for the Braille dictionary." The dictionary referred to is the Webster's Student Dictionary published in 1968 by the American Printing House for the Blind. It has never been updated, and although it has been superseded by newer mainframe or CD-ROM dictionaries that can be accessed through voice synthesis, there is a growing debate on the need for Braille as a mandatory subject in schools for the visually impaired. 
In 1989 the number of Braille readers in school was about 12 percent. ${ }^{17}$ However, because Braille is becoming as easy to produce through the advancement of microcomputer technology as a taped copy of a book, it is entirely possible that the population of Braille readers will increase in colleges and universities across the United States.

\section{Library staff members need to identify and communicate with their disabled population in order to provide necessary services and equipment.}

Equipment and adaptive technologies, in those libraries reporting, range from the reliable hand magnifier to the technologically advanced computerbased scanner/reader. Several of the libraries that have adaptive equipment report that it is seldom used. Among the reasons for this are a lack of publicity regarding services offered and a lack of knowledge concerning the disabled student population. Many of the libraries do not provide much in terms of adaptive technology. The low number of libraries providing equipment directly relates to the 80 percent which provide funding of services through their own budgets. The state of Alabama has prorated its education budget three times in the last ten years. Library budgets have decreased. These budgets in turn continually are being eaten away by rising serial and monographic costs.

\section{CONCLUSION}

It is difficult to draw conclusions from this study. The survey population is extremely small, and is not easily compared with existing data from other sources. Alabama librarians are aware of the ADA, but are not sure how to comply. More needs to be done within the state in terms of education and training. Library staff members need to identify and communicate with their disabled population in order to provide necessary services and equipment.

This survey of Alabama state-supported university libraries poses more questions than it answers. The lack of information on persons with disabilities and academic libraries shows that more studies need to be done. Questions that need to be answered include: Does the institution's age, size, location, and budget affect its accessibility? Are libraries in a particular geographic region more accessible than those in another? How does the library director's attitude toward persons with disabilities affect the library's accessibility both physically and attitudinally? Are older libraries less likely to be accessible than newer ones?

This was one view of one state's response to persons with disabilities. How does Alabama compare with other states? The ARL survey is a good starting place, but it only looks at the larger institutions. Are the other libraries comparable to the small, medium, and large libraries surveyed here? After all, there are only two ARL libraries in the state (Auburn University and the University of Alabama), and when the ARL survey was done, Auburn was not an ARL member.

These questions and others are yet to be answered. A survey of this nature should be done every few years, especially if the ADA is strictly enforced. This initial survey may indicate where Alabama's libraries are now, where they are going, and what they have accomplished. The ADA will not go away; therefore, librarians need to begin the process of complying; if they do not do so voluntarily, it is entirely conceivable that they will be forced to comply legally.

\section{REFERENCES AND NOTES}

1. James L. Thomas and Carol H. Thomas, Academic Library Facilities and Services for the Handicapped (Phoenix, Ariz.: Oryx, 1981), ix.

2. "Services to the Disabled in ARL Libraries," Spec Kit 81 (Washington, D.C.: Association of Research Libraries, Office of Management Studies, 1982), iii-iv. 
3. Sue O. Medina to Dr. William C. Highfill, letter, Nov. 3, 1993.

4. The institutions surveyed are Alabama Agricultural \& Mechanical University, Alabama State University, Auburn University, Auburn University at Montgomery, Jacksonville State University, Livingston University, Troy State University, Troy State University at Dothan, Troy State University in Montgomery, The University of Alabama, University of Alabama at Birmingham, University of Alabama in Huntsville, University of Montevallo, University of North Alabama, University of South Alabama.

5. Joseph P. Shapiro, No Pity: People with Disabilities Forging a New Civil Rights Movement (New York: Times Books, 1993), 175.

6. Department of Education, National Center for Education Statistics, Profile of Handicapped Students in Postsecondary Education, 1987 (Washington, D.C.: Government Printing Office, 1989), 5.

7. Department of Education, National Center for Education Statistics, Digest of Education Statistics 1989 (Washington, D.C.: Government Printing Office, 1989), 190.

8. Department of Education, National Center for Education Statistics, Digest of Education Statistics, 1992, (Washington, D.C.: Government Printing Office, 1992), 195.

9. Laura F. Rothstein, "Campuses and the Disabled," Chronicle of Higher Education (Sept. 4, 1991): B3.

10. Ibid., B10.

11. Eric L. Dey, Alexander W. Astin, and William S. Korn, The American Freshman: Twenty-Five Year Trends (Los Angeles: Cooperative Institutional Research Program, University of California, 1991), 101.

12. Alexander W. Astin, and others, The American Freshman: National Norms for Fall of 1991 (Los Angeles: Cooperative Institutional Research Program, University of California, 1991), 18.

13. Eric L. Dey, and others, The American Freshman: National Norms for Fall of 1992 (Los Angeles: Cooperative Institutional Research Program, University of California, 1992), 16.

14. Julia Gustafson and Kerry Langan, "Academic Library Services and the Learning Disabled College Student," Library Services for the Learning Disabled, (Buffalo, N.Y.: The Western New York Library Resources Council, June 8, 1990). Reprint ERIC ED333899, 9-10.

15. "Library Services for Persons with Disabilities," Spec Kit 176 (Washington, D.C.: Association of Research Management, Office of Management Services, 1991), 5.

16. A Guide to the Auburn University Libraries (Auburn, Ala.: Auburn University Libraries, 1993) and A Guide to the Ralph Brown Draughon Library (Auburn, Ala.: Auburn University Libraries, 1993).

17. Karen De Witt, "How Best to Teach the Blind: A Growing Battle over Braille," New York Times, May 12, 1991, sec. 2, p. 1, col. 4.

\section{APPENDIX A SURVEY}

"Library Services for Persons with Disabilities," SPEC Kit 176. Washington, D.C.: Association of Research Libraries, Office of Management Services, 1991. Used with permission of the Association of Research Libraries Office of Management Services, Washington, D.C.

\section{GENERAL INFORMATION}

1. Does the library have/provide services and/or equipment designed for persons with disabilities?

_ Yes__ No

2. In your opinion, has the use of the library by patrons with disabilities increased in the past five years?

_Yes_No 
If YES, why do you think that this has happened? (Use back of sheet, if necessary.) Increased enrollment of students with disabilities

Library providing more services; also better promotion of services

- Improved services on campus encourages more students to attend and to identify themselves

_ University actively recruiting; outreach service

_Universitywide promotion and awareness of services

- Changing attitudes of persons with disabilities; more independent; greater awareness of legal rights

Mainstreaming resulting in more students academically prepared to attend university

- Increased publicity and use of library in general

_ More (and better) adaptive equipment available

3. Does the library have a checklist for building accessibility? Please provide a copy of the checklist.

_ Yes__ No

4. Indicate areas in which the library has made improvements in library accessibility for patrons with disabilities during the past five years. (Check all that apply.)

_ Elimination of physical barriers

- Addition of specialized equipment/adaptive technologies

_ Adding specialized library services

- Staff devoted to providing library service for patrons with disabilities

- Other (please explain)

5. Which disabilities are specifically addressed through specialized library services? (Check all that apply.)

Blind and visually impaired

- Deaf and hearing impaired

— Learning disabled

- Physically impaired

- Other (please specify)

\section{MANAGEMENT AND TRAINING}

6. With which other units on campus does the library cooperate or coordinate in providing specialized services? (Check all that apply.)

_ Office for Disabled Students

- Student Services

- Computer Center

- Counseling Center

_ Learning Center

_ Not applicable

_ Student Government

_ Other (please specify)

7. What is/are the source(s) of funding for providing special library services for patrons with disabilities? (Check all that apply.)

_ Library budget

- Other campus office

_ Office for Disabled Students

- Office of Student Affairs

_ Physical Plant

- Office of Equal Opportunity

_ Gifts/endowments

_ Grant(s)

_ Agency

_ Other (please specify) 
8. Has the library completed cost analyses for providing specialized services? If budgetary documents are available, please provide copies.

- Yes No

9. Has the library prepared planning documents, project reports, or lists of recommendations concerning library services for patrons with disabilities? (Please provide a copy of these documents.)

_ Yes _ No

10. Is the library (or any other unit on campus) taking steps to heighten awareness among library faculty and staff of the special needs of library patrons with disabilities? (Include sample materials and/or other information.)

- Yes No

11. Does the library (or any other unit on campus) provide the staff with specific instructions for assisting patrons with disabilities in the event of an emergency? (Please provide copy of instructions.)

_ Yes_ No

12. Who conducts training for library staff in providing specialized services and in the use of equipment designed for use by persons with disabilities? (Check all that apply.)

Librarians

_ Disabled Students Office

- Vendors

_ Persons with disabilities

- Vocational rehabilitation

- No training provided at this time

_ Other

13. Who attends these training sessions? (Check all that apply.)

_ Circulation Department

— Reference Department

_ Librarians in all public service areas

_ Support staff in all public service areas

_Patrons with disabilities

— Student assistants

- Other

14. Does the library have a librarian or staff member who coordinates library services for patrons with disabilities? Please provide a position description.

_ Yes__ No

15. If yes, indicate the amount of time this employee devotes to this responsibility:

Full-time

- Half-time

- Other

\section{SPACE FOR SPECIALIZED LIBRARY SERVICES}

16. What space does the library set aside specifically for library services for those with disabilities? Please provide floor diagrams showing square footage and placement of furnishing and equipment.

- Separate room(s)

- Scattered individual workstations

- Dedicated space within a larger room

— None (please skip to question 20) 
17. What is the location of the room/space for specialized library services? Main library

- Branch library

_ All libraries

18. What are the hours of operation for this area? (Check all that apply.)

- Same hours of operation as the library

- Monday-Friday, business hours

Monday-Friday, evenings

Evenings

- Other

19. Who provides assistance for patrons using space set aside for patrons with disabilities?

\section{SERVICES}

20. Does the library have written policies for providing library services for the disabled? Please provide a copy of these policies.

_ Yes _ No _ Other

21. Have the policies for providing services for library patrons with disabilities been revised in the past five years?

_ Yes _ No

If yes, in what way have the policies been changed?

22. Does the library provide for patrons a statement on and/or a description of specialized library services available in the library? Please provide a copy of such documents.

— Yes _ No

23. Which of the following library services for persons with disabilities are provided by the library? (Check all that apply.)

_ Paging of materials from the stacks

- Looking up material in library catalog

_ Photocopy service

_ Accessible public telephones

— Telephone renewals

_ Accessible photocopiers

- Telephone requests

_ Specialized bibliographic instruction

— Referral services

- Delivery service

Extended loan periods

Reading to the blind

_ Recording of textbooks or other reading materials

Giving examinations

Signing with the deaf/hearing impaired

Other

24. Is the library's online catalog equipped with:

Print enlargement? Yes No

In all libraries?

Speech synthesis? Yes No

In all libraries?

Other 
25. Do the blind library patrons at your institution use Braille?

26. In what ways does the library communicate with patrons with disabilities concerning ways the library might be more effective in serving their informational needs? (Check all that apply.)

Consultations with individuals with disabilities

Suggestion box

Advisory committee (staff and disabled)

Survey

Workshops

Consultation with Office for Disabled Students

Consultation with other campus offices

Written correspondence with those who self-identify

Consultations with vendors

Consultations with professional ADA consultants

27. What specialized equipment or adaptive technologies are available in the library for use by patrons with disabilities? How often is this equipment used? (Check all that apply.) Please include a list of specialized equipment/adaptive technologies (including manufacturer) available in the library.

Reading machine

Screen enlargement

Cassette tape recorder

Hand magnifier

Tape recorder (variable speech)

Braille typewriter

CCTV

TTY/TDD

Talking calculator

Speech synthesis

Reel-to-reel tape recorder

Braille printer

Typewriter, large print

Tactile reader

Page turner

Hand held scanner

Other

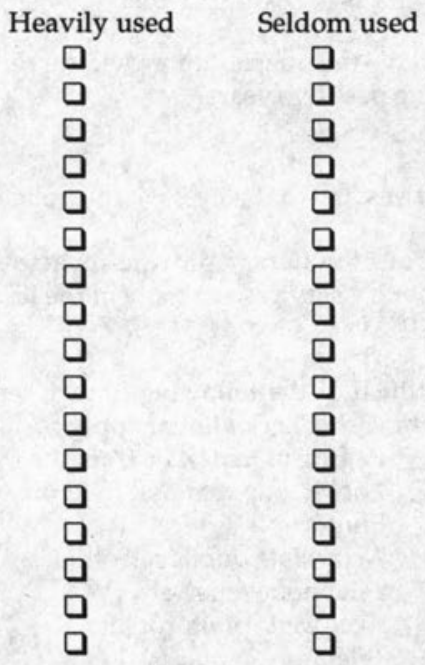

\section{GENERAL COMMENTS}

Please include any additional comments about library service for persons with disabilities on the back of this sheet. 